\title{
Notícia: A Wilhelm Reich aos 50 Anos de sua Morte
}

\author{
Sara Quenzer Matthiesen ${ }^{1}$ \\ Universidade Estadual de São Paulo - Campus de Rio Claro.
}

\section{News: For Wilhelm Reich on the 50th Anniversary of his Death}

Hoje, 111 anos após seu nascimento - em 24 de março de 1896 - e 50 anos após sua morte - em 03 de novembro de 1957, são muitos os que ainda se perguntam: mas, quem foi Reich afinal?

Ora, foi o primogênito de Cacile Roniger e Leon Reich, nascido no final do século XIX em Dobrzynica, integrante do, na época, Império Austro-Húngaro, diriam alguns estudiosos. Foi um judeu, ainda que não praticante, educado, conforme o desejo da família, nos moldes da cultura alemã, diriam outros.

Reich, na verdade, foi um discípulo e depois dissidente do grande pai da Psicanálise, Sigmund Freud, diriam àqueles familiarizados com suas contribuições iniciais. Mas não apenas isso, diriam os interessados por política, Reich foi membro ativo do Partido Comunista, encabeçando inúmeros trabalhos sociais ainda que dele tenha sido expulso em 1933.

Reich foi um desequilibrado, um verdadeiro louco, um charlatão, diriam aqueles que, preconceituosamente, se referem a esse belíssimo autor sem que tenham o mínimo de conhecimento e dignidade.

Pois, Reich, eu diria, foi um autor, homem e pesquisador, ímpar! Foi ele quem inovou a técnica terapêutica inserindo o corpo na clínica; foi ele quem se preocupou com o esclarecimento sexual da população quando o tema era ainda mais tabu do que é atualmente; foi ele quem se preocupou com as "crianças do futuro" deixando registrado em seu testamento (Reich, 2001), seu desejo por um mundo melhor e mais justo.

Em função de suas idéias e pesquisas polêmicas, não isentas de maiores aprofundamentos, Reich foi preso... morreu na prisão poucos meses depois, ao mesmo tempo em que deixou ao mundo o registro infindo de idéias e colaborações para as mais diferentes áreas do conhecimento.

Entretanto, é preciso lembrar que a amplitude de sua obra, as dificuldades de acesso aos originais, os problemas de muitas das traduções, somadas ao fato de ser judeu e comunista, certamente, foram alguns dos responsáveis pelas dificuldades de propagação de suas idéias. Pior que isso, foi o preconceito gerado em torno de algumas delas e de sua pessoa, que afastaram - e ainda afastam - muitos que poderiam dar prosseguimento às suas descobertas.

No Brasil, aquilo que se conhece de Reich parece se aproximar mais do campo clínico do que de outras de suas frentes de pesquisa. Nos Centros de Formação, espalhados

1 Endereço: Departamento de Educação Física, Av. 24A n. 1515, Bairro Bela Vista, Rio Claro, SP, Brasil 13506-900.E-mail: saraqm@ rc.unesp.br pelo Brasil afora, a discussão de suas idéias ocorre com mais nitidez, ao passo que no campo universitário isso ainda ocorre de forma tímida. Não é preciso ir muito longe! Basta pensarmos em quantos de nós estudamos Reich, com o devido aprofundamento, na graduação ou em quantos de nós tivemos a oportunidade de conversarmos sobre Reich durante nossas vidas.

Mas não sejamos injustos, a ponto de desconsiderar o aumento significativo em termos de produção, sobretudo, acadêmica, nos últimos tempos. Só para que se tenha uma idéia, em 2002, o livro "Caminhos das pedras: as publicações de Wilhelm Reich em português" (Matthiesen, 2002), revelava a existência de 11 dissertações de mestrado entre 1982-2001 e oito teses de doutorado entre 1979-2001, num total de 19 produções, até agosto de 2001. Alguns anos depois, em a "Organização bibliográfica da obra de Wilhelm Reich: bases para o aprofundamento em diferentes áreas do conhecimento" (Matthiesen, 2007) verificou-se, num período mais amplo, isto é, de 1979 a setembro de 2005, 56 pesquisas (41 dissertações de mestrado e 17 teses de doutorado) voltadas ao pensamento reichiano.

Os resultados demonstram que, iniciados em 1979, esses trabalhos intensificaram-se, a partir de 2000, sobretudo no doutorado. Assim, das três dissertações de mestrado da década de 1980, passou-se, na década de 1990, a 13 produções, registrando um aumento significativo que se manteve com a entrada no segundo milênio, registrando 24 produções. Razões para isso não faltam e vão desde a ampliação dos Cursos de Pós-Graduação, dada a necessidade de titulação para a docência no Ensino Superior, até um "retorno a Reich", como um referencial passível de reflexão acerca dos problemas cotidianos, comprovando a atualidade de seus colaborações.

Em especial, no que diz respeito às produções do doutorado, nota-se que entre o primeiro trabalho defendido em 1979 até os dias atuais, foram mais intensas as publicações nos últimos anos, talvez pelo próprio interesse de alguns profissionais em dar continuidade às pesquisas desenvolvidas durante o mestrado. Assim, depois desse trabalho isolado defendido em 1979, somente nos anos de 1990 é que se inicia a produção de mais cinco teses cujas defesas se multiplicaram com a entrada do novo milênio, passando de cinco para 11 numa única década. Portanto, em termos numéricos houve um aumento significativo, reforçado pela qualidade, sempre constante, dos trabalhos produzidos nesse universo.

Reich, entretanto, merece mais! Merece ser incorporado aos Cursos de Graduação e Pós-graduação das diferentes áreas; merece integrar a agenda dos eventos universitários; merece ser discutido com os educadores, dada sua importância para a educação e, mais que isso: merece respeito e 
seriedade na difusão de suas idéias. Aliás, é a isso que se tem prestado as disciplinas - ainda que poucas - ministradas na graduação e pós-graduação ${ }^{2}$-; os vários livros que têm sido publicados e as produções acadêmicas aqui analisadas, nos permitindo reafirmar que houve um aumento no interesse por Reich nos últimos anos. Talvez, pela necessidade de se registrar formalmente aquilo que se fazia empiricamente; de uma sistematização do pensamento reichiano a partir de diferentes perspectivas, ou por ser uma referência ímpar no trato de temas hoje tão a flor da pele como é o caso da sexualidade, do corpo e do movimento.

Aliás, tão animador quanto suas idéias, as produções acadêmicas confirmam não apenas a atualidade de seu pensamento, mas a sua magnitude, fazendo-o presente não apenas em Programas de Pós-gradução de universidades particulares, mas, de universidades públicas; não apenas em Programas de Pós-graduação em Psicologia, mas em Educação, Ciências da Comunicação, Artes, Música, Ciência Política, Ciências Sociais, Sexologia, Educação Física, História das Ciências, entre outros, explicitando suas contribuições para diferentes áreas do conhecimento.

Hoje, 111 anos após seu nascimento e 50 anos após sua morte, poderíamos dizer, sem medo de errar, que seu pensamento tem penetrado - ainda que não com a amplitude que merece - os diferentes ramos do conhecimento, comprovando, na atualidade, a atualidade de suas idéias.

\section{Referências}

Matthiesen, S. Q. (2002). Caminhos das pedras: as publicações de Wilhelm Reich em português. Rio Claro: Majograf.

Matthiesen, S. Q. (2007). Organização bibliográfica da obra de Wilhelm Reich: bases para o aprofundamento em diferentes áreas do conhecimento. São Paulo: Annablume/Fapesp.

Reich, W. (2001). Último desejo e testamento de Wilhelm Reich. Tradução de Sara Quenzer Matthiesen. Psicologia: Teoria e Pesquisa, 17(3), 207-210.
2 O Programa de Pós-graduação em "Ciências da Motricidade" da Unesp-Rio Claro, oferece a disciplina: "Criança, corpo e educação: contribuições reichianas para a educação Física".
Recebido em 28.06.2007

Aceito em 20.08.2007 